\title{
Characterization of French Coriander Oil as Source of Petroselinic Acid
}

\author{
Evelien Uitterhaegen $1,2,3,+$, Klicia A. Sampaio ${ }^{3,4,+}$, Elisabeth I. P. Delbeke ${ }^{3}$, Wim De Greyt ${ }^{5}$, \\ Muriel Cerny ${ }^{1,2}$, Philippe Evon ${ }^{1,2}$, Othmane Merah ${ }^{1,2}$, Thierry Talou ${ }^{1,2}$ and \\ Christian V. Stevens ${ }^{3, *}$
}

1 Laboratoire de Chimie Agro-Industrielle, Université de Toulouse, INP, ENSIACET, 4 Allée Emile Monso, BP 44362, 31030 Toulouse Cedex 4, France; Evelien.Uitterhaegen@ensiacet.fr (E.U.);

Muriel.Cerny@ensiacet.fr (M.C.); Philippe.Evon@ensiacet.fr (P.E.); Othmane.Merah@ensiacet.fr (O.M.);

Thierry.Talou@ensiacet.fr (T.T.)

2 Laboratoire de Chimie Agro-Industrielle, Institut National de la Recherche Agronomique, 31030 Toulouse Cedex 4, France

3 SynBioC, Department of Sustainable Organic Chemistry and Technology, Ghent University, Coupure Links 653, B-9000 Ghent, Belgium; Klicia_Sampaio@yahoo.com.br (K.A.S.);

Elisabeth.Delbeke@UGent.be (E.I.P.D.)

4 EXTRAE, Food Engineering Department, University of Campinas, Rua Monteiro Lobato, 80, 13083-862 Campinas-São Paulo, Brazil

5 Desmet-Ballestra Group, Corporate Village, Da Vincilaan 2, 1935 Zaventem, Belgium;

Wim.De.Greyt@desmetballestra.com

* Correspondence: Chris.Stevens@UGent.be; Tel.: +32-9-264-5957

+ The first two authors have both participated equally to this work. Therefore, they are both considered as principal authors.

Academic Editors: James H. Clark and Thomas J. Farmer

Received: 4 August 2016; Accepted: 6 September 2016; Published: 8 September 2016

\begin{abstract}
Coriander vegetable oil was extracted from fruits of French origin in a 23\% yield. The oil was of good quality, with a low amount of free fatty acids (1.8\%) and a concurrently high amount of triacylglycerols (98\%). It is a rich source of petroselinic acid (C18:1n-12), an important renewable building block, making up $73 \%$ of all fatty acids, with also significant amounts of linoleic acid $(14 \%)$, oleic acid $(6 \%)$, and palmitic acid $(3 \%)$. The oil was characterized by a high unsaponifiable fraction, comprising a substantial amount of phytosterols $(6.70 \mathrm{~g} / \mathrm{kg})$. The main sterol markers were $\beta$-sitosterol (35\% of total sterols), stigmasterol (24\%), and $\Delta^{7}$-stigmastenol $(18 \%)$. Squalene was detected at an amount of $0.2 \mathrm{~g} / \mathrm{kg}$. A considerable amount of tocols were identified $(500 \mathrm{mg} / \mathrm{kg}$ ) and consisted mainly of tocotrienols, with $\gamma$-tocotrienol as the major compound. The phospholipid content was low at $0.3 \%$, of which the main phospholipid classes were phosphatidic acid (33\%), phosphatidylcholine (25\%), phosphatidylinositol (17\%), and phosphatidylethanolamine $(17 \%)$. About $50 \%$ of all phospholipids were non-hydratable. The $\beta$-carotene content was low at $10 \mathrm{mg} / \mathrm{kg}$, while a significant amount of chlorophyll was detected at about $11 \mathrm{mg} / \mathrm{kg}$. An iron content of $1.4 \mathrm{mg} / \mathrm{kg}$ was determined through element analysis of the vegetable oil. The influence of fruit origin on the vegetable oil composition was shown to be very important, particularly in terms of the phospholipids, sterols, and tocols composition.
\end{abstract}

Keywords: Coriandrum sativum L.; vegetable oil; petroselinic acid; tocols; phytosterols

\section{Introduction}

Coriandrum sativum L. is an annual herb from the Apiaceae (Umbelliferae) family that originates from the Near East and Mediterranean area. Currently, India is its main producer with an annual production of around 500,000 tonnes [1]. It is mainly applied as a spice but has also found applications 
in perfumery and cosmetics, owing to its spicy citrus flavor. Next to this, coriander is well known as a medicinal herb and has been shown to exhibit antioxidant [2], antimicrobial [3,4], anti-inflammatory [5], anxiolytic [6], antidepressant [7], and hypoglycemic activities [8].

Coriander fruits are marked by the presence of two distinct oil fractions, i.e., a vegetable oil and an essential oil fraction, the former being extractable continuously by mechanical pressing of the fruits using twin-screw extrusion technology [9]. While the vegetable oil content of the fruits is typically between $20 \%$ and $28 \%$, the essential oil fraction is much smaller with contents of $0.3 \%$ to $0.9 \%$ [10]. Both the vegetable and the essential oil are characterized by the presence of a key compound, i.e., petroselinic acid and linalool, respectively, representing about $70 \%$ of the respective oil fraction. Petroselinic acid is particularly interesting as it constitutes a rather uncommon fatty acid mainly found in the seeds from Apiaceae crops. It represents a positional isomer of oleic acid with its double bond situated at the 6-position rather than the 9-position, which makes it an interesting building block for the chemical industry [11].

Coriander vegetable oil has recently been labelled as a Novel Food Ingredient (NFI) and has been proven safe for consumption as a food supplement by healthy adults with a maximum of $600 \mathrm{mg} /$ day [12]. Next to this, the presence of petroselinic acid gives rise to a wide array of opportunities for coriander vegetable oil. The fatty acid has been shown to exhibit some attractive properties such as anti-aging and anti-inflammatory activity, leading to its application in the cosmetic and functional food industry $[13,14]$. Further, petroselinic acid displays significant potential for the chemical industry. Oxidative cleavage leads to industrially interesting compounds, as this renders both lauric acid, a commercial surfactant; and adipic acid, a precursor for Nylon 66 [15]. As this position of the double bond is a rather rare feature amongst octadecenoic acids, derivatization may result in the synthesis of some unique and potentially interesting oleochemicals. A recent study dealing with the use of petroselinic acid for the fermentation of novel sophorolipids has shown that petroselinic acid can be isolated from French coriander oil in a high yield of $80 \%$ through alkaline hydrolysis of the vegetable oil and subsequent crystallization in absolute ethanol [11]. Baird and Preskett describe the processing of Apiaceae seeds to obtain a solid component rich in petroselinic acid through extraction and crystallization [16].

Most analytical studies have focused on the essential oil part of coriander fruits, while some studies were conducted on vegetable oil extracted from Tunisian, German, and Canadian coriander fruits [17-19]. This study aims to provide a full characterization of the vegetable oil extracted from coriander fruits of French origin, which, to the best knowledge of the authors, has not been the subject of any previous studies. Further, determination of the element content of coriander vegetable oil has never been reported. The importance of these results lies within the industrial potential of coriander vegetable oil, as its lipid profile and minor compounds greatly contribute to its added value for several industries.

\section{Results and Discussion}

\subsection{Vegetable Oil Yield}

$n$-Hexane solvent extraction of coriander fruits of French origin yielded a vegetable oil with $22.9 \% \pm 1.0 \%$ on a dry weight basis. This is in accordance with the oil yield range of $20 \%-28 \%$ mentioned by Sahib et al. for coriander fruits [10]. Sriti et al. obtained an oil yield of $22 \%$ and $16 \%$ for Tunisian and Canadian coriander fruits, respectively [18] A different study reported oil yields ranging between $15 \%$ and $26 \%$ for Tunisian coriander fruits, depending on the fruit maturity [20]. Vietnamese coriander fruits rendered a $20 \%$ oil yield upon $n$-hexane solvent extraction, while this was only $11 \%$ for Turkish coriander fruits [21,22]. This confirms the strong dependence of the fruit oil content on fruit origin, variety, maturity, and cultivation conditions.

Several studies applied different extraction methods to obtain the coriander vegetable oil. A 2:1 mixture of chloroform and methanol was used to extract the oil from German coriander fruits, leading 
to a high oil yield of $28 \%$ [19]. Kozłowska et al. compared $n$-hexane and 2:1 chloroform/methanol as extracting solvents for Polish coriander oil and found oil yields of $20 \%$ and $22 \%$, respectively [23]. British coriander fruits were extracted using the method of Welch, which utilizes $2 \%$ sulphuric acid in methanol as a solvent, with a resulting oil yield of $17 \%-19 \%$ [24]. A sustainable process using supercritical $\mathrm{CO}_{2}$ extraction and subsequent separation of essential and vegetable oil was applied for Canadian coriander fruits by Mhemdi et al. resulting in an oil yield of $19 \%$, representing $90 \%$ of the yield obtained through $n$-hexane solvent extraction [25]. Mechanical pressing has been applied for the extraction of coriander oil without the use of hazardous solvents. For Tunisian coriander fruits, single-screw and twin-screw extrusion lead to an oil yield representing $65 \%$ and $47 \%$, respectively, of that obtained through solvent extraction [26,27]. Twin-screw extrusion of French coriander fruits led to a similar oil recovery of $47 \%$ [9]. This illustrates the significantly higher extraction capacity of solvent extraction as opposed to mechanical pressing.

\subsection{Vegetable Oil Composition}

The coriander vegetable oil composition was determined through GC and consists of $97.83 \% \pm 1.06 \%$ of triglycerides (TAG), $1.05 \% \pm 0.09 \%$ of diglycerides (DAG), $0.09 \% \pm 0.02 \%$ of monoglycerides (MAG) and $1.03 \% \pm 0.03 \%$ of FFA, expressed as petroselinic acid The FFA content was also determined through titration, which led to a higher value $(1.80 \%)$. This difference may be explained by the fact that through titration, all acidic compounds are neutralized by $\mathrm{NaOH}$. These compounds comprise free fatty acids but also other components that show an acidic character, such as phospholipids. The high amount of TAG and concurrent low FFA content demonstrates that little hydrolysis or enzymatic degradation has occurred in the oil. Similar results were reported by Sriti et al. and Ramadan and Mörsel for Tunisian and German coriander oil, respectively, although in the latter only $91 \%$ of TAG and $6 \%$ of FFA were detected $[17,19]$. It is important to highlight that the FFA content is indicative of the oil quality.

\subsection{Fatty Acid Profile}

The distribution and identification of fatty acids in the vegetable oil (Table 1) was determined through gas chromatography of their methyl ester form. From this, it is clear that petroselinic acid (C18:1n-12) is the major fatty acid in coriander vegetable oil, constituting $72.6 \%$ of all fatty acids. Other important fatty acids are linoleic acid (C18:2) and oleic acid (C18:1n-9), representing about 14\% and $6 \%$ of all fatty acids, respectively. Other vegetable oils with similar fatty acid compositions include parsley and celery oil, both rich in petroselinic acid (75\% and $64 \%$, respectively) and originating from the Apiaceae family [28]. Further, coriander oil is often compared to high-oleic sunflower oil, which shows a similar composition but has oleic acid, a positional isomer of petroselinic acid, as a major compound (70\%-87\%) [29].

The results obtained for French coriander oil are similar to the fatty acid profiles found in literature for coriander oil, for which the amount of petroselinic acid ranges from $52 \%$ and $66 \%$ for Italian and German coriander oil, respectively, to $79 \%$ for Vietnamese coriander oil [21,30,31]. Intermediate values of about $72 \%-76 \%$ were reported for Canadian, Tunisian, Polish, British, Indian, and Turkish coriander oil [18,22-24,32]. This leads to the conclusion that the fatty acid profile of coriander vegetable oil is not highly dependent on the geographical location [10]. 
Table 1. Fatty acid profile of coriander vegetable oil.

\begin{tabular}{|c|c|}
\hline Fatty Acid & Content (\%) \\
\hline C6:0 & $0.1 \pm 0.1$ \\
\hline C16:0 & $2.9 \pm 0.1$ \\
\hline C16:1 & $0.4 \pm 0.1$ \\
\hline C16:1t & $0.2 \pm 0.1$ \\
\hline $\mathrm{C} 16: 1 \mathrm{c}$ & $0.2 \pm 0.1$ \\
\hline C17:0 & $<0.1$ \\
\hline C18:1t & $0.7 \pm 0.1$ \\
\hline C18:0 & $<0.1$ \\
\hline C18:1n-12 & $72.6 \pm 0.4$ \\
\hline C18:1n-9 & $6.0 \pm 0.3$ \\
\hline C18:1n-7 & $1.2 \pm 0.1$ \\
\hline C18:2 & $13.8 \pm 0.3$ \\
\hline C18:2t & $0.1 \pm 0.1$ \\
\hline $\mathrm{C} 18 \mathrm{a} 2 \mathrm{C}$ & $13.7 \pm 0.3$ \\
\hline C18:3 & $0.2 \pm 0.1$ \\
\hline C18:3t & $0.1 \pm 0.1$ \\
\hline $\mathrm{C} 18: 3 \mathrm{c}$ & $0.1 \pm 0.1$ \\
\hline C20:0 & $0.1 \pm 0.1$ \\
\hline C20:1 & $0.2 \pm 0.1$ \\
\hline SFA & $3.2 \pm 0.1$ \\
\hline MUFA & $81.2 \pm 0.4$ \\
\hline PUFA & $14.0 \pm 0.3$ \\
\hline Identified & $98.3 \pm 0.2$ \\
\hline
\end{tabular}

SFA: saturated fatty acids; MUFA: monounsaturated fatty acids; PUFA: polyunsaturated fatty acids.

\subsection{Sterol Composition}

The sterol composition of coriander vegetable oil of French origin is presented in Table 2. The oil is a rich source of phytosterols, comprising a total amount of about $6.70 \mathrm{~g} / \mathrm{kg}$. Most vegetable oils show lower sterol contents of between 1 and $5 \mathrm{~g} / \mathrm{kg}$, e.g., olive oil with a sterol content of 1.2-2.8 g/ $\mathrm{kg}$ [33,34]. Edible oils that are rich in phytosterols include rapeseed oil $(7.5 \mathrm{~g} / \mathrm{kg})$ and corn oil $(14 \mathrm{~g} / \mathrm{kg})$ [33]. Phytosterols are of importance for the pharmaceutical industry as they are applied as raw materials for steroid production. Next to this, they have been added to margarines and table spreads due to their cholesterol-lowering capacity [35]. The most important compound was found to be $\beta$-sitosterol, constituting about $35 \%$ of all sterols. Other major compounds include stigmasterol, $\Delta^{7}$-stigmastenol, and campesterol at $24 \%, 18 \%$, and $8 \%$ of total sterols, respectively. Besides this, squalene, a compound of interest for the cosmetic industry, was detected in the unsaponifiable matter at an amount of $0.19 \pm 0.01 \mathrm{~g} / \mathrm{kg}$ oil. Most vegetable oils contain $0.05-0.50 \mathrm{~g} / \mathrm{kg}$ squalene, while rich vegetable sources include olive oil $(1.6 \mathrm{~g} / \mathrm{kg})$ and amaranthus oil $(70 \mathrm{~g} / \mathrm{kg})$ [33]. Figure 1 presents the obtained chromatogram from sterol analysis. Sunflower oil shows a similar sterol composition, with $\beta$-sitosterol as the main compound representing a more important fraction of $42 \%-70 \%$, while its total sterol content is significantly lower at $2-5 \mathrm{~g} / \mathrm{kg}$ [29].

A similar composition was reported by Sriti et al. for Tunisian and Canadian coriander oil, although significant amounts of $\Delta^{5,24}$-stigmastadienol were detected, while this was not detected for French coriander oil $[17,18,36]$. In German, Hungarian, and Polish coriander oil, stigmasterol and $\beta$-sitosterol were found in equal amounts, both representing $25 \%-30 \%$ of all sterols, while no $\Delta^{7}$-stigmastenol was detected and $\Delta^{5}$-avenasterol was more important at about $25 \%$ for German and 
Hungarian coriander oil and 15\% for Polish coriander oil [19,23,31]. Reported total sterol contents were always significantly lower than those determined for coriander oil of French origin. Hungarian, Tunisian, and Canadian coriander oil contained between 6.0 and $6.3 \mathrm{~g} / \mathrm{kg}$ sterols, while this was $5.2 \mathrm{~g} / \mathrm{kg}$ for German coriander oil and only $3.5 \mathrm{~g} / \mathrm{kg}$ for Polish coriander oil $[18,19,23,31,36]$. From this, it is clear that the sterol composition of coriander vegetable oil is strongly dependent on the fruit origin. This has also been reported for other important vegetable oils, such as olive oil, where the sterol content and composition was found to be highly dependent on olive cultivar, fruit ripening, and agro-environmental conditions $[37,38]$.

Table 2. Sterol composition of coriander vegetable oil.

\begin{tabular}{|c|c|}
\hline Sterol & Content (g/kg) \\
\hline Cholesterol & $0.02 \pm 0.01$ \\
\hline Campesterol & $0.54 \pm 0.01$ \\
\hline Stigmasterol & $1.61 \pm 0.02$ \\
\hline$\beta$-Sitosterol & $2.31 \pm 0.03$ \\
\hline$\Delta^{5}$-Avenasterol & $0.27 \pm 0.01$ \\
\hline$\Delta^{7}$-Stigmastenol & $1.22 \pm 0.03$ \\
\hline$\Delta^{7}$-Avenasterol & $0.40 \pm 0.01$ \\
\hline Gramisterol & $0.07 \pm 0.01$ \\
\hline Citrostadienol & $0.10 \pm 0.01$ \\
\hline Cycloartenol & $0.08 \pm 0.01$ \\
\hline Methylene cycloartanol & $0.06 \pm 0.01$ \\
\hline Total sterols & $6.68 \pm 0.02$ \\
\hline
\end{tabular}

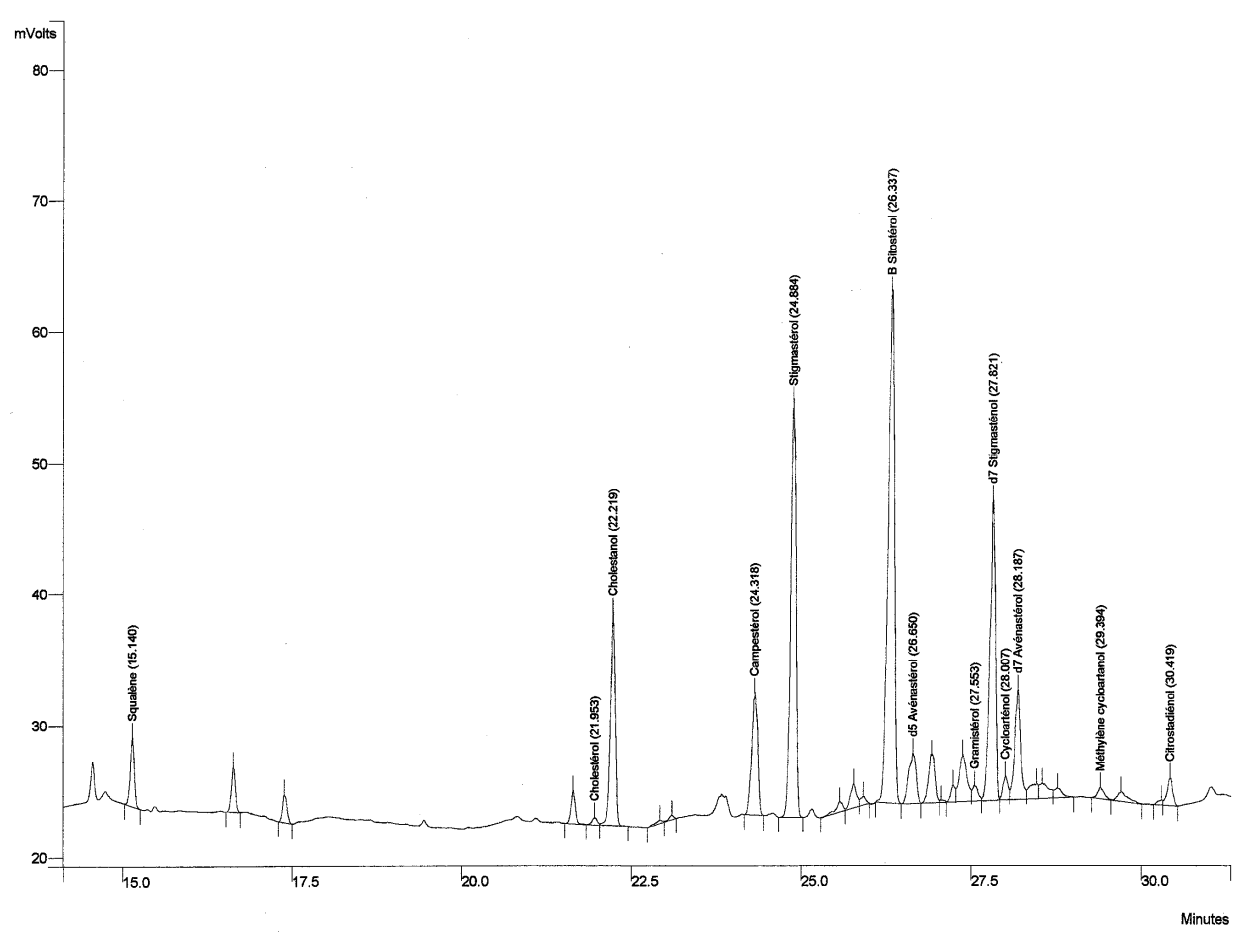

Figure 1. Gas chromatogram from sterol analysis of coriander vegetable oil.

\subsection{Tocols Composition}

The composition of tocopherols and tocotrienols was measured using HPLC and is listed in Table 3. The total amount of tocols is about $500 \mathrm{mg} / \mathrm{kg}$, which is an intermediate value as vegetable oils usually contain between 200 and $800 \mathrm{mg} / \mathrm{kg}$ tocols [33], and will protect the oil from oxidative reactions. 
The most prominent compound is $\gamma$-tocotrienol, representing $71 \%$ of all tocols. Other important compounds are $\alpha$-tocotrienol and $\delta$-tocotrienol at $20 \%$ and $5 \%$ of all tocols, respectively. Tocotrienols constitute about $95 \%$ of all tocols, which is interesting as these compounds have shown great antioxidant capacity and biological activities when compared to tocopherols $[39,40]$.

Table 3. Tocol composition of coriander and palm oil ( $\mathrm{mg} / \mathrm{kg})$.

\begin{tabular}{ccc}
\hline Tocol & Coriander Oil & Palm Oil \\
\hline$\alpha$-tocopherol & $12.4 \pm 0.1$ & 147.5 \\
$\alpha$-tocotrienol & $98.0 \pm 2.0$ & 146.8 \\
$\beta$-tocopherol & n.d. & n.d. \\
$\gamma$-tocopherol & $10.1 \pm 0.2$ & 19.5 \\
$\gamma$-tocotrienol & $350.3 \pm 6.7$ & 283.0 \\
$\delta$-tocopherol & n.d. & n.d. \\
$\delta$-tocotrienol & $25.7 \pm 0.3$ & 49.7 \\
Total tocols & $496.5 \pm 8.3$ & 646.5 \\
\hline
\end{tabular}

This composition resembles that of palm oil (Table 3), while sunflower oil is rich in $\alpha$-tocopherol (400-1100 mg/kg) and typically contains only traces of tocotrienols [29]. The results are consistent with results reported by Matthaus et al. for Vietnamese coriander oil [21]. Tunisian and Canadian coriander oil were shown to exhibit a similar tocol composition, although a significantly lower total amount of tocols was found at about 330 and $210 \mathrm{mg} / \mathrm{kg}$, respectively [17,18]. Coriander fruits of Belgian origin were reported to contain a very low amount of tocols $(53 \mathrm{mg} / \mathrm{kg})$ with $\delta$-tocopherol as the main compound and only $6 \mathrm{mg} / \mathrm{kg}$ of tocotrienols [41]. Some studies only reported data on the tocopherol fraction. For coriander oil from the USA, Moser and Vaughn found a total amount of $230 \mathrm{mg} / \mathrm{kg}$ tocopherols with a high level of $\alpha$-tocopherol (196 mg/kg) [42]. Hungarian coriander oil showed a very high level of tocopherols $(1270 \mathrm{mg} / \mathrm{kg})$ with $\beta$-tocopherol as the major compound, making up $50 \%$ of all tocopherols, while no $\beta$-tocopherol was detected for French coriander oil [31]. The tocols composition of vegetable oils is strongly affected by fruit origin and cultivation conditions, as well as the oil extraction method [43].

\subsection{Phospholipid Composition}

The phospholipid composition of coriander vegetable oil was determined using ${ }^{31} \mathrm{P}-\mathrm{NMR}$ and is presented in Table 4 . The total phospholipid content resulting from this analysis amounts to $0.31 \%$, of which the major phospholipid subclass was found to be phosphatidic acid (PA), constituting $33 \%$ of all phospholipids. Other important classes are phosphatidylcholine (PC) at $25 \%$ and phosphatidylinositol (PI) and phosphatidylethanolamine (PE), both representing about $17 \%$ of all phospholipids. The low phospholipid content of French coriander oil may present advantages during further refining, in particular degumming. Many commercially important crude edible oils are rich in phospholipids, e.g., soybean oil (3.2\%), rapeseed oil (2.5\%), and sunflower oil (1.5\%), and need further refining [33].

Table 4. Phospholipid composition of coriander vegetable oil.

\begin{tabular}{cc}
\hline Phospholipid Subclass & \% by Weight \\
\hline Phosphatidic acid & $32.5 \pm 1.0$ \\
Phosphatidylcholine & $25.4 \pm 2.9$ \\
Phosphatidylinositol & $17.0 \pm 4.7$ \\
Phosphatidylethanolamine & $16.7 \pm 2.7$ \\
Phosphatidyl glycerol & $8.1 \pm 0.5$ \\
1-lysophosphatidylcholine & $0.5 \pm 0.3$ \\
\hline
\end{tabular}


In literature, the total amount of phospholipids in coriander oil ranges widely. It varied from $1.5 \%$ to $2.0 \%$ for German and Tunisian coriander oil, Hungarian coriander oil contained about $0.9 \%$ of phospholipids and Prasad et al. reported a very low total amount of phospholipids (0.1\%) for Indian coriander oil $[19,31,32,44]$. For all these oils, a similar composition was reported with PC as the major compound $(36 \%-45 \%)$ and significant amounts of PE $(25 \%-32 \%)$ and PI $(10 \%-13 \%)[19,32,44]$. The other interesting fact is related to the presence of PA as the major phospholipid in French coriander oil, since in coriander oil from German, Tunisian, or Indian origin, PA was either not detected [19] or detected in amounts of less than $10 \%[17,32,44]$.

\subsection{Pigments Content}

Both the $\beta$-carotene and chlorophyll content of French coriander vegetable oil was measured using UV spectrophotometry. The $\beta$-carotene content is low at $10.1 \pm 0.9 \mathrm{mg} / \mathrm{kg}$ compared to palm oil displaying very high $\beta$-carotene contents of 500 to $1500 \mathrm{mg} / \mathrm{kg}$ [45]. Ramadan and Mörsel have reported a very high $\beta$-carotene content of $890 \mathrm{mg} / \mathrm{kg}$ for Hungarian coriander vegetable oil [31]. The amount of chlorophyll was found to be relatively high at $11.1 \mathrm{mg} / \mathrm{kg}$. Canola oil is known as the commercial vegetable oil with the highest chlorophyll contents and contains at most $30 \mathrm{mg} / \mathrm{kg}$ of chlorophyll [46]. High chlorophyll contents may impart undesirable oil color and render the oil more susceptible to oxidation [46]. As a comparison, sunflower oil contains very low amounts of pigments, showing carotenoid and chlorophyll contents of only 1-1.5 and 0.2-0.5 mg/kg, respectively [29]. To the best knowledge of the authors, no previous studies have reported the chlorophyll content of coriander oil.

\subsection{Elements Content}

The levels of various elements in coriander vegetable oil were determined using ICP analysis and resulted in the values presented in Table 5 . The iron content is acceptable at $1.4 \mathrm{mg} / \mathrm{kg}$ as the standard for crude vegetable oils is set at $5.0 \mathrm{mg} / \mathrm{kg}$ [47]. As an example, crude rapeseed oil shows an iron content of $3.5 \mathrm{mg} / \mathrm{kg}$ [48]. These metal traces present an important factor for the oxidative stability of the oil. The phosphorus level of $230 \mathrm{mg} / \mathrm{kg}$ is rather low as most crude vegetable oils display phosphorus contents between 200 and $800 \mathrm{mg} / \mathrm{kg}$, while crude rapeseed oil shows a high phosphorus content of $1190 \mathrm{mg} / \mathrm{kg}$ [48,49]. The non-hydratable amount of phospholipids may be determined as the sum of the calcium and magnesium content and constitutes about $50 \%$ of all phosphorous. This may present a problem for further degumming as the removal of non-hydratable phospholipids requires more complex processes with the use of phosphoric or citric acid [50]. However, recent developments of enzymatic degumming have resulted in an environmentally friendly alternative that reduces the use of chemicals [51].

The total amount of $0.31 \%$ of phospholipids, determined through ${ }^{31} \mathrm{P}-\mathrm{NMR}$, corresponds to about $131 \mathrm{mg} / \mathrm{kg}$ of phosphorous coming from phospholipids (Table 5). This was determined through calculation of the average P/PL factor (0.042) for coriander oil. Of this amount, a little more than half comes from hydratable phospholipids (HPL) such as PC, while the rest comes from non-hydratable phospholipids (NHPL) such as PA. Taking into account the phosphorous content of $230 \mathrm{mg} / \mathrm{kg}$ detected by ICP, about $100 \mathrm{mg} / \mathrm{kg}$ of phosphorous contained within the vegetable oil comes from an origin other than phospholipids, e.g., inorganic phosphates, glycophospholipids or phytic acid, an important storage compound for phosphorous in seeds.

Table 5. Elements content of coriander vegetable oil $(\mathrm{mg} / \mathrm{kg})$.

\begin{tabular}{|c|c|c|c|c|c|c|c|c|c|}
\hline $\mathrm{Ca}$ & $\mathrm{Fe}$ & K & $\mathrm{Mg}$ & $\mathrm{Na}$ & $\mathbf{P}$ & $\begin{array}{l}\text { P from PL } \\
\text { (NMR) }\end{array}$ & HPL & NHPL & $\begin{array}{l}\text { P Different } \\
\text { Origin }\end{array}$ \\
\hline $92.8 \pm 0.8$ & $1.4 \pm 0.1$ & $73.1 \pm 0.5$ & $35.8 \pm 0.2$ & $5.2 \pm 0.1$ & $230.7 \pm 0.4$ & $131.2 \pm 8.9$ & $75.2 \pm 7.8$ & $56.4 \pm 3.1$ & $99.5 \pm 8.9$ \\
\hline
\end{tabular}




\section{Materials and Methods}

\subsection{Material}

Coriander fruits were supplied by GSN Semences (Le Houga, France). They consisted of the GSN maintenaire variety and were cultivated in the southwestern part of France. The fruit moisture content was determined gravimetrically according to ISO $665: 2000$ and was $9.77 \% \pm 0.10 \%$ [52].

\subsection{Chemicals and Reagents}

Tocopherol standards were obtained from Calbiochem (San Diego, CA, USA). $\beta$-carotene and chlorophyll standards were procured from Fluka (Buchs, Switzerland). Sterol standards, tricaprin, glycerin, monoolein, diolein, triolein, butanetriol, and betulin were purchased from Sigma-Aldrich (St. Louis, MO, USA) and Acros Organics (Morris Plains, NJ, USA). All reagents used in this study were purchased from Sigma-Aldrich, Merck (Darmstadt, Germany), Chem-Lab (Zedelgem, Belgium), or Fisher Scientific (Hampton, NH, USA) and were either analytical or HPLC grade.

\subsection{Lipid Extraction}

Milling of the fruits was executed with a Retsch (Haan, Germany) miller, model ZM100, at $18,000 \mathrm{rpm}$. For further milling of the cake between extraction steps, a $0.75 \mathrm{~mm}$ sieve was applied. Oil extraction was carried out according to ISO 659:2009 with a Soxhlet apparatus and $n$-hexane as the extracting solvent [53].

\subsection{Physicochemical Analyses}

The free fatty acid (FFA) content was determined by titration according to AOCS Ca 5a-40 [54]. The elements content was analyzed through inductively coupled plasma (ICP) analysis (iCAP 6000 series, Thermo Scientific, Waltham, MA, USA) according to AOCS Ca 17-01 and Ca 20-99 [55,56]. The $\beta$-carotene content was determined by UV spectrophotometry (UV-1800, Shimadzu, Kyoto, Japan), measuring the absorbance of samples diluted with iso-octane at $446.0 \mathrm{~nm}$. The chlorophyll content was determined according to AOCS Cc 13i-96 with a Shimadzu UV-1800 spectrophotometer [57].

\subsection{Gas Chromatography}

\subsubsection{Vegetable Oil Composition}

The vegetable oil composition was measured according to the AOCS method Cd 11b-91 [58]. Analytical conditions: chromatograph, Agilent 7890A GC system (Santa Clara, CA, USA); column, Agilent DB-5HT (5\% phenyl-methylpolysiloxane), $15 \mathrm{~m} \times 0.32 \mathrm{~mm} \times 0.10 \mu \mathrm{m}$; helium as the carrier gas at a rate of $5 \mathrm{~mL} / \mathrm{min}$; cold-on-column injection with an injection volume of $1 \mu \mathrm{L}$; column temperature of $50-200{ }^{\circ} \mathrm{C}\left(15{ }^{\circ} \mathrm{C} / \mathrm{min}\right), 200-290^{\circ} \mathrm{C}\left(3^{\circ} \mathrm{C} / \mathrm{min}\right), 290^{\circ} \mathrm{C}$ for $10 \mathrm{~min}, 290-360^{\circ} \mathrm{C}\left(10{ }^{\circ} \mathrm{C} / \mathrm{min}\right), 360{ }^{\circ} \mathrm{C}$ for $15 \mathrm{~min}$; flame ionization detector (FID) with a temperature of $380^{\circ} \mathrm{C}$. The fatty compounds were identified using authentic standards (glycerin, oleic acid, monoolein, diolein, and triolein), as described in the method.

\subsubsection{Acid Composition}

Fatty acid methyl esters were prepared according to the AOCS method Ce 2-66 [59]. Analytical conditions: chromatograph, Agilent 6890N GC System; column, Agilent DB-23 (50\% cyanopropyl-methylpolysiloxane), $30 \mathrm{~m} \times 0.25 \mathrm{~mm} \times 0.25 \mu \mathrm{m}$; helium as the carrier gas at a rate of $1.0 \mathrm{~mL} / \mathrm{min}$; injection temperature of $250{ }^{\circ} \mathrm{C}$; column temperature of $110^{\circ} \mathrm{C}$ for $5 \mathrm{~min}, 110-215^{\circ} \mathrm{C}$ $\left(5{ }^{\circ} \mathrm{C} / \mathrm{min}\right), 215^{\circ} \mathrm{C}$ for $24 \mathrm{~min}$; detection temperature of $280{ }^{\circ} \mathrm{C}$. The fatty acid methyl esters were identified by comparison with external standards purchased from Nu Check Inc. (Elysian, Chicago, IL, USA). 


\subsubsection{Sterol Composition}

The method used to analyze the sterol composition was based on the one used by Roche et al. [60]. Exactly $100 \mu \mathrm{g}$ of cholestanol was added as an internal standard through a $2 \mathrm{mg} / \mathrm{mL}$ solution in chloroform. After chloroform evaporation, vegetable oil samples of $100 \mathrm{mg}$ were added. Saponification was carried out through addition of $2 \mathrm{~mL}$ of a $1 \mathrm{M}$ potassium hydroxide in ethanol solution. Samples were vortex mixed and heated to $75^{\circ} \mathrm{C}$ for $20 \mathrm{~min}$ in a water bath. After cooling to ambient temperature, the unsaponifiable matter was extracted through the addition of $1 \mathrm{~mL}$ of distilled water and $6 \mathrm{~mL}$ of cyclohexane and vortex mixing. After separation of the layers, the organic phase was collected. $160 \mu \mathrm{L}$ of the extract was silylated by adding $40 \mu \mathrm{L}$ of a 1\% TMCS in BSTFA solution. Samples were subjected to GC analysis.

Analytical conditions: chromatograph, Perkin Elmer AutoSystem GC system (Waltham, MA, USA); column, Varian CPSil 8CB (5\% phenyl-dimethylpolysiloxane), $30 \mathrm{~m} \times 0.25 \mathrm{~mm} \times 0.25 \mu \mathrm{m}$; helium as the carrier gas with a column head pressure of $100 \mathrm{kPa}$; on-column injection with an injection volume of $1 \mu \mathrm{L}$; injection temperature of $55^{\circ} \mathrm{C}$ for $0.5 \mathrm{~min}, 55-360{ }^{\circ} \mathrm{C}\left(200{ }^{\circ} \mathrm{C} / \mathrm{min}\right), 360^{\circ} \mathrm{C}$ for $30 \mathrm{~min}$; column temperature of $160{ }^{\circ} \mathrm{C}$ for $0.5 \mathrm{~min}, 160-260^{\circ} \mathrm{C}\left(20^{\circ} \mathrm{C} / \mathrm{min}\right), 260^{\circ} \mathrm{C}$ for $5.5 \mathrm{~min}, 260-300{ }^{\circ} \mathrm{C}$ $\left(2{ }^{\circ} \mathrm{C} / \mathrm{min}\right), 300{ }^{\circ} \mathrm{C}$ for $10 \mathrm{~min}, 300-360{ }^{\circ} \mathrm{C}\left(45^{\circ} \mathrm{C} / \mathrm{min}\right), 360{ }^{\circ} \mathrm{C}$ for $3 \mathrm{~min}$; detection temperature of $360^{\circ} \mathrm{C}$.

\subsection{High-Performance Liquid Chromatography}

Tocopherols and tocotrienols were analyzed through HPLC according to AOCS Ce 8-89 [61]. Analytical conditions: chromatograph, Agilent 1260 Infinity HPLC system; pump, G1511C quaternary pump; column, Grace normal phase, $250 \mathrm{~mm} \times 4.6 \mathrm{~mm} \times 5 \mu \mathrm{m}$; detector, HP series 110 fluorescence detector with an extinction of $290 \mathrm{~nm}$ and an emission of $330 \mathrm{~nm}$; $n$-hexane/2-propanol $(99.5 / 0.5 \mathrm{v} / \mathrm{v})$ as the mobile phase at a rate of $1 \mathrm{~mL} / \mathrm{min}$ at isocratic conditions; injection volume of $20 \mu \mathrm{L}$; column temperature of $25^{\circ} \mathrm{C}$; runtime of $30 \mathrm{~min}$. The tocotrienol isomer contents were calculated based on the standard peak areas of their related tocopherol analogs.

\subsection{Nuclear Magnetic Resonance}

Determination and identification of the phospholipid content was carried out according to the ${ }^{31} \mathrm{P}-\mathrm{NMR}$ quantification method from Spectral Service GmbH (Köln, Germany) [62]. NMR analyses were performed on a Bruker Avance III Nanobay $400 \mathrm{MHz}$ NMR spectrometer (Bruker, Billerica, MA, USA) with a $5 \mathrm{~mm}$ BBFO Z-gradient high-resolution probe. ${ }^{31} \mathrm{P}-\mathrm{NMR}$ spectra were recorded at $162 \mathrm{MHz}$. Results were processed using Topspin software (Topspin 3.5, Bruker).

Vegetable oil samples of between 500 and $600 \mathrm{mg}$ were weighed. $5 \mathrm{mg}$ of triphenyl phosphate was added as an internal standard. $1.5 \mathrm{~mL}$ of a $1 / 1 / 1$ solvent mixture of $\mathrm{CDCl}_{3}$, methanol and a $0.2 \mathrm{M}$ Cs-EDTA solution was added. Samples were stirred for $5 \mathrm{~min}$ and centrifuged at $4000 \mathrm{rpm}$ for $5 \mathrm{~min}$ for the separation of the layers. $0.5 \mathrm{~mL}$ of the lower organic phase was collected and subjected to ${ }^{31}$ P-NMR analysis.

All analyses were carried out in triplicate and results are presented as the mean \pm the standard deviation (SD).

\section{Conclusions}

Coriandrum sativum $\mathrm{L}$. represents an interesting novel renewable resource, exhibiting a wide range of biological activities and containing both an essential oil and a vegetable oil fraction. This study comprises a full characterization of the vegetable oil fraction of French coriander fruits. This oil was shown to be of good quality and rich in petroselinic acid, an uncommon positional isomer of oleic acid and important renewable building block. Further, the oil contains a fair amount of tocols, of which $95 \%$ are tocotrienols, exhibiting strong antioxidant capacity, with $\gamma$-tocotrienol as the major compound. Next to this, French coriander oil was found to be particularly rich in phytosterols, industrially 
important compounds with significant human health benefits, with an amount of $6.70 \mathrm{~g} / \mathrm{kg}$ and $\beta$-sitosterol as the main sterol marker. As part of the unsaponifiable matter, squalene was detected at $0.2 \mathrm{~g} / \mathrm{kg}$. Further, significant differences between coriander fruit origins were detected in the phospholipids, where the French coriander oil showed a substantially lower total amount of only $0.3 \%$ with phosphatidic acid as the major compound. A low $\beta$-carotene content $(10 \mathrm{mg} / \mathrm{kg})$ and a significant amount of chlorophyll were detected. The amount of iron in the oil was acceptable at $1.4 \mathrm{mg} / \mathrm{kg}$. This study has shown that the coriander fruit origin has a significant influence on the composition of the vegetable oil, with phospholipids, phytosterols, tocols, and pigments as the main compounds being affected. It was further shown that the French variety may have high industrial potential through the presence of significant amounts of phytosterols and tocotrienols and a high petroselinic acid content.

Acknowledgments: The authors wish to express their sincere gratitude to Desmet Ballestra for allowing the use of their equipment and assisting in the experiments and analyses executed for the purpose of this study.

Author Contributions: E. Uitterhaegen and K.A. Sampaio have contributed equally to this work and have both participated in the experimental work and writing of the manuscript. E.I.P. Delbeke has made a significant contribution to the experimental work and correction of the manuscript. W.D. Greyt has kindly enabled the use of equipment and materials at Desmet Ballestra and has provided useful insight into obtained results and important modifications to the manuscript. M. Cerny has provided substantial assistance in the analysis and discussion of the sterol composition. P. Evon, O. Merah and T. Talou have contributed to the experimental work of this study and the writing and correcting of the manuscript. C.V. Stevens has made a key contribution to this study through overseeing the experimental work, providing insight into the analytical results and providing substantial assistance with the writing of the manuscript.

Conflicts of Interest: The authors declare no conflict of interest.

\section{References}

1. Sharma, R.P.; Singh, R.S.; Verma, T.P.; Tailor, B.L.; Sharma, S.S.; Singh, S.K. Coriander the taste of vegetables: Present and future prospectus for coriander seed production in southeast Rajasthan. Econ. Aff. 2014, 59, 345-354. [CrossRef]

2. Wangensteen, H.; Samuelsen, A.B.; Malterud, K.E. Antioxidant activity in extracts from coriander. Food Chem. 2004, 88, 293-297. [CrossRef]

3. Kubo, I.; Fujita, K.; Kubo, A.; Nihei, K.; Ogura, T. Antibacterial activity of coriander volatile compounds against Salmonella choleraesuis. J. Agric. Food Chem. 2004, 52, 3329-3332. [CrossRef] [PubMed]

4. Rattanachaikunsopon, P.; Phumkhachorn, P. Potential of coriander (Coriandrum sativum) oil as a natural antimicrobial compound in controlling Campylobacter jejuni in raw meat. Biosci. Biotechnol. Biochem. 2010, 74, 31-35. [CrossRef] [PubMed]

5. Reuter, J.; Huyke, C.; Casetti, F.; Theek, C.; Frank, U.; Augustin, M.; Schempp, C. Anti-inflammatory potential of a lipolotion containing coriander oil in the ultraviolet erythema test. J. Dtsch. Dermatol. Ges. 2008, 6, 847-851. [CrossRef] [PubMed]

6. Mahendra, P.; Bisht, S. Anti-anxiety activity of Coriandrum sativum assessed using different experimental anxiety models. Indian J. Pharmacol. 2011, 43, 574-577. [CrossRef] [PubMed]

7. Kharade, S.M.; Gumate, D.S.; Patil, V.M.; Kokane, S.P.; Naikwade, N.S. Behavioral and biochemical studies of seeds of Coriandrum Sativum in various stress models of depression. Int. J. Curr. Res. Rev. 2011, 3, 4-11.

8. Eidi, M.; Eidi, A.; Saeidi, A.; Molanaei, S.; Sadeghipour, A.; Bahar, M.; Bahar, K. Effect of coriander seed (Coriandrum sativum L.) ethanol extract on insulin release from pancreatic beta cells in streptozotocin-induced diabetic rats. Phytother. Res. 2009, 23, 404-406. [CrossRef] [PubMed]

9. Uitterhaegen, E.; Nguyen, Q.H.; Sampaio, K.A.; Stevens, C.V.; Merah, O.; Talou, T.; Rigal, L.; Evon, P. Extraction of coriander oil using twin-screw extrusion: Feasibility study and potential press cake applications. J. Am. Oil Chem. Soc. 2015, 92, 1219-1233. [CrossRef]

10. Sahib, N.G.; Anwar, F.; Gilani, A.H.; Hamid, A.A.; Saari, N.; Alkharfy, K.M. Coriander (Coriandrum sativum L.): A potential source of high-value components for functional foods and nutraceuticals-A review. Phytother. Res. 2013, 27, 1439-1456. [PubMed] 
11. Delbeke, E.I.P.; Everaert, J.; Uitterhaegen, E.; Verweire, S.; Verlee, A.; Talou, T.; Soetaert, W.; van Bogaert, I.N.A.; Stevens, C.V. Petroselinic acid purification and its use for the fermentation of new sophorolipids. AMB Express 2016, 6. [CrossRef] [PubMed]

12. European Food Safety Authority (EFSA). Scientific opinion on the safety of "coriander seed oil" as a Novel Food Ingredient. EFSA J. 2013, 11, 3422-3442.

13. Alaluf, S.; Green, M.R.; Powell, J.R.; Rogers, J.S.; Watkinson, A.; Cain, F.W.; Hu, H.L.; Rawlings, A.V. Petroselinic Acid and Its Use in Food. U.S. Patent 6,365,175 B1, 2 April 2002.

14. Alaluf, S.; Hu, H.L.; Green, M.R.; Powell, J.R.; Rawlings, A.V.; Rogers, J.S. Cosmetic Use of Petroselinic Acid. Patent EP 1,013,178 B1, 28 September 2005.

15. Kleiman, R. Chemistry of new industrial oilseed crops. In Advances in New Crops; Janick, J., Simon, J.E., Eds.; Timber Press: Portland, OR, USA, 1990; pp. 196-203.

16. Baird, M.S.; Preskett, D. Method of Obtaining a Solid Component Rich in a Petroselinic Compound. U.S. Patent 2011/0009487, 13 January 2011.

17. Sriti, J.; Wannes, W.; Talou, T.; Mhamdi, B.; Cerny, M.; Marzouk, B. Lipid profiles of Tunisian Coriander (Coriandrum sativum) seed. J. Am. Oil Chem. Soc. 2010, 87, 395-400. [CrossRef]

18. Sriti, J.; Talou, T.; Msaada, K.; Marzouk, B. Comparative analysis of fatty acid, sterol and tocol composition of Tunisian and Canadian Coriander (Coriandrum sativum L.) fruit. Anal. Chem. Lett. 2011, 1, 375-383. [CrossRef]

19. Ramadan, M.; Mörsel, J.-T. Oil composition of coriander (Coriandrum sativum L.) fruit-seeds. Eur. Food Res. Technol. 2002, 215, 204-209. [CrossRef]

20. Msaada, K.; Hosni, K.; Taarit, M.B.; Hammami, M.; Marzouk, B. Effects of growing region and maturity stages on oil yield and fatty acid composition of coriander (Coriandrum sativum L.) fruit. Sci. Hortic. 2009, 120, 525-531. [CrossRef]

21. Matthaus, B.; Vosmann, K.; Pham, L.Q.; Aitzetmüller, K. FA and tocopherol composition of Vietnamese oilseeds. J. Am. Oil Chem. Soc. 2003, 80, 1013-1020. [CrossRef]

22. Kiralan, M.; Calikoglu, E.; Ipek, A.; Bayrak, A.; Gurbuz, B. Fatty acid and volatile oil composition of different coriander (Coriandrum sativum) registered varieties cultivated in Turkey. Chem. Nat. Compd. 2009, 45, 100-102. [CrossRef]

23. Kozłowska, M.; Gruczyńska, E.; Ścibisz, I.; Rudzińska, M. Fatty acids and sterols composition, and antioxidant activity of oils extracted from plant seeds. Food Chem. 2016, 213, 450-456. [CrossRef] [PubMed]

24. Griffiths, D.W.; Robertson, G.W.; Millam, S.; Holmes, A.C. The determination of the petroselinic acid content of coriander (Coriandrum sativum) oil by capillary gas chromatography. Phytochem. Anal. 1992, 3, 250-253. [CrossRef]

25. Mhemdi, H.; Rodier, E.; Kechaou, N.; Fages, J. A supercritical tuneable process for the selective extraction of fats and essential oil from coriander seeds. J. Food Eng. 2011, 105, 609-616. [CrossRef]

26. Sriti, J.; Talou, T.; Faye, M.; Vilarem, G.; Marzouk, B. Oil extraction from coriander fruits by extrusion and comparison with solvent extraction processes. Ind. Crops Prod. 2011, 33, 659-664. [CrossRef]

27. Sriti, J.; Msaada, K.; Talou, T.; Faye, M.; Amalia Kartika, I.; Marzouk, B. Extraction of coriander oil by twin-screw extruder: Screw configuration and operating conditions effect. Ind. Crops Prod. 2012, 40, 355-360. [CrossRef]

28. Ngo-Duy, C.-C.; Destaillats, F.; Keskitalo, M.; Arul, J.; Angers, P. Triacylglycerols of Apiaceae seed oils: Composition and regiodistribution of fatty acids. Eur. J. Lipid Sci. Technol. 2009, 111, 164-169. [CrossRef]

29. Gunstone, F.D. Sunflower oil. In Vegetable Oils in Food Technology: Composition, Properties and Uses; Wiley-Blackwell: Chichester, UK, 2011; pp. 137-168.

30. Guidotti, M.; Ravasio, N.; Psaro, R.; Gianotti, E.; Coluccia, S.; Marchese, L. Epoxidation of unsaturated FAMEs obtained from vegetable source over Ti(IV)-grafted silica catalysts: A comparison between ordered and non-ordered mesoporous materials. J. Mol. Catal. A Chem. 2006, 250, 218-225. [CrossRef]

31. Ramadan, M.F.; Mörsel, J.-T. Oxidative stability of black cumin (Nigella sativa L.), coriander (Coriandrum sativum L.) and niger (Guizotia abyssinica Cass.) crude seed oils upon stripping. Eur. J. Lipid Sci. Technol. 2004, 106, 35-43. [CrossRef]

32. Prasad, R.B.N.; Rao, Y.N.; Rao, S.V. Phospholipids of palash (Butea monosperma), papaya (Carica papaya), jangli badam (Sterculia foetida), coriander (Coriandrum sativum) and carrot (Daucus carota) seeds. J. Am. Oil Chem. Soc. 1987, 64, 1424-1427. [CrossRef] 
33. Gunstone, F.D. Vegetable oils. In Bailey's Industrial Oil and Fat Products; Shahidi, F., Ed.; Wiley-Interscience: New York, NY, USA, 2005; pp. 213-267.

34. Matthaus, B.; Özcan, M.M. Determination of fatty acid, tocopherol, sterol contents and 1,2- and 1,3-diacylglycerols in four different virgin olive oil. J. Food Process. Technol. 2011, 2, 117-120. [CrossRef]

35. Law, M.R. Plant sterol and stanol margarines and health. West. J. Med. 2000, 173, 43-47. [CrossRef] [PubMed]

36. Sriti, J.; Talou, T.; Wannes, W.A.; Cerny, M.; Marzouk, B. Essential oil, fatty acid and sterol composition of Tunisian coriander fruit different parts. J. Sci. Food Agric. 2009, 89, 1659-1664. [CrossRef]

37. Chehade, A.; Bitar, A.E.; Kadri, A.; Choueiri, E.; Nabbout, R.; Youssef, H.; Smeha, M.; Awada, A.; Chami, Z.A.; Dubla, E.; et al. In situ evaluation of the fruit and oil characteristics of the main Lebanese olive germplasm. J. Sci. Food Agric. 2016, 96, 2532-2538. [CrossRef] [PubMed]

38. Jbara, G.; Jawhar, A.; Bido, Z.; Cardone, G.; Dragotta, A.; Famiani, F. Fruit and oil characteristics of the main Syrian olive cultivars. Ital. J. Food Sci. 2010, 22, 395-400.

39. Suzuki, Y.J.; Tsuchiya, M.; Wassall, S.R.; Choo, Y.M.; Govil, G.; Kagan, V.E.; Packer, L. Structural and dynamic membrane properties of alpha-tocopherol and alpha-tocotrienol: Implication to the molecular mechanism of their antioxidant potency. Biochemistry 1993, 32, 10692-10699. [CrossRef] [PubMed]

40. Sen, C.K.; Khanna, S.; Roy, S. Tocotrienols: Vitamin E beyond tocopherols. Life Sci. 2006, 78, $2088-2098$. [CrossRef] [PubMed]

41. Horvath, G.; Wessjohann, L.; Bigirimana, J.; Jansen, M.; Guisez, Y.; Caubergs, R.; Horemans, N. Differential distribution of tocopherols and tocotrienols in photosynthetic and non-photosynthetic tissues. Phytochemistry 2006, 67, 1185-1195. [CrossRef] [PubMed]

42. Moser, B.R.; Vaughn, S.F. Coriander seed oil methyl esters as biodiesel fuel: Unique fatty acid composition and excellent oxidative stability. Biomass Bioenergy 2010, 34, 550-558. [CrossRef]

43. Kamal-Eldin, A.; Appelqvist, L.-Å. The chemistry and antioxidant properties of tocopherols and tocotrienols. Lipids 1996, 31, 671-701. [CrossRef] [PubMed]

44. Sriti, J.; Wannes, W.A.; Talou, T.; Mhamdi, B.; Hamdaoui, G.; Marzouk, B. Lipid, fatty acid and tocol distribution of coriander fruit's different parts. Ind. Crops Prod. 2010, 31, 294-300. [CrossRef]

45. Sampaio, K.A.; Ayala, J.V.; Silva, S.M.; Ceriani, R.; Verhé, R.; Meirelles, A.J.A. Thermal Degradation Kinetics of Carotenoids in Palm Oil. J. Am. Oil Chem. Soc. 2013, 90, 191-198. [CrossRef]

46. Daun, J.K. Spectrophotometric analysis of chlorophyll pigments in canola and rapeseed oils. Lipid Technol. 2012, 24, 134-136. [CrossRef]

47. Codex Alimentarius Commission. Codex Alimentarius: Fats, Oils and Related Products; Food and Agriculture Organization: Rome, Italy, 2001.

48. Gunstone, F.D. Canola/rapeseed oil. In Vegetable Oils in Food Technology: Composition, Properties and Uses; Wiley-Blackwell: Chichester, UK, 2011; pp. 107-136.

49. Erickson, D.R. Edible Fats and Oils Processing: Basic Principles and Modern Practices: World Conference Proceedings; American Oil Chemists' Society: Champaign, IL, USA, 1990.

50. Zufarov, O.; Schmidt, Š.; Sekretár, S. Degumming of rapeseed and sunflower oils. Acta Chim. Slovaca 2008, 1, 321-328.

51. Sampaio, K.A.; Zyaykina, N.; Wozniak, B.; Tsukamoto, J.; De Greyt, W.; Stevens, C.V. Enzymatic degumming: Degumming efficiency versus yield increase. Eur. J. Lipid Sci. Technol. 2015, 117, 81-86. [CrossRef]

52. ISO. ISO 665:2000, Oilseeds-Determination of Moisture and Volatile Matter Content; International Organization for Standardization: Geneva, Switzerland, 2000.

53. ISO. ISO 659:2009, Oilseeds-Determination of oil Content; International Organization for Standardization: Geneva, Switzerland, 2009.

54. AOCS. AOCS Method Ca 5a-40, Free fatty acids. In Official Methods and Recommended Practices of the AOCS; AOCS Press: Champaign, IL, USA, 1997.

55. AOCS. AOCS Method Ca 17-01, Trace elements in oil by ICP-OES. In Official Methods and Recommended Practices of the AOCS; AOCS Press: Champaign, IL, USA, 1997.

56. AOCS. AOCS Method Ca 20-99, Phosphorus in oil by ICP-OES. In Official Methods and Recommended Practices of the AOCS; AOCS Press: Champaign, IL, USA, 1997.

57. AOCS. AOCS Method Cc 13i-96, Chlorophyll pigments (crude vegetable oils). In Official Methods and Recommended Practices of the AOCS; AOCS Press: Champaign, IL, USA, 1997. 
58. AOCS. AOCS Method Cd 11b-91, Determination of mono- and diglycerides by capillary gas chromatography. In Official Methods and Recommended Practices of the AOCS; AOCS Press: Champaign, IL, USA, 1997.

59. AOCS. AOCS Method Ce 2-66, Preparation of methyl esters of fatty acids. In Official Methods and Recommended Practices of the AOCS; AOCS Press: Champaign, IL, USA, 1997.

60. Roche, J.; Alignan, M.; Bouniols, A.; Cerny, M.; Mouloungui, Z.; Vear, F.; Merah, O. Sterol content in sunflower seeds (Helianthus annuus L.) as affected by genotypes and environmental conditions. Food Chem. 2010, 121, 990-995. [CrossRef]

61. AOCS. AOCS Method Ce 8-89, Tocopherols and tocotrienols in vegetable oil and fats by HPLC. In Official Methods and Recommended Practices of the AOCS; AOCS Press: Champaign, IL, USA, 1997.

62. Diehl, B. NMR spectroscopy of natural substances. In NMR Spectroscopy in Pharmaceutical Analysis; Holzgrabe, U., Wawer, I., Diehl, B., Eds.; Elsevier B.V.: Oxford, UK, 2008; pp. 181-200.

Sample Availability: Samples of the compounds coriander vegetable oil and petroselinic acid are available from the authors.

(C) 2016 by the authors; licensee MDPI, Basel, Switzerland. This article is an open access article distributed under the terms and conditions of the Creative Commons Attribution (CC-BY) license (http:/ / creativecommons.org/licenses/by/4.0/). 